hire of the film are available from the Television Service, University of Glasgow, Glasgow G12 8LB; telephone 041-339 0424.

\section{Clinical Immunology}

The G.M. Lancisi International Prize for Medical Science, value 10 million lire, is this year on the subject of clinical immunology. Work submitted for the prize must be original and unpublished and may be in English or Italian. Further details are available from Premio Internazionale Scientifico "G.M. Lancisi," Pio Instituto di S. Spirito -Borgo S. Spirito 3, 00193 Rome, or from the British Council, Spring Gardens, London W.1.

\section{Teaching Seminars}

The Committee on Teaching Aids of the Council for Postgraduate Medical Education in England and Wales is arranging seminars to help those responsible for providing courses and instruction in postgraduate medical centres. Two pilot seminars have been arranged, but as the number of applications to attend has greatly exceeded the number of places available it is expected that further seminars will be arranged later this year and next.

\section{Bangla Desh Medical Association}

Dr. Nurul Alam and Dr. Nazrul Islam have been elected president and general secretary of the Bangla Desh Medical Association in the United Kingdom for the year 1975-76. Doctors from Bangla Desh are invited to contact the association at its temporary address, 11 Burstow Road, London S.W.20.

\section{Prix André Lichtwitz}

The Prix Andre Lichtwitz (8000 franes) is offered each year by the Institut National de la Santé et de la Recherche Médicale for outstanding research on calcium and phosphorus metabolism, either in the field of chemical or experimental biology or in basic science. Applications should reach the director, I.N.S.E.R.M., for the attention of Dr. Bonnot, 101 rue de Tolbiac, 75645 Paris Cedex 13 before 13 June. Applicants should send eight copies (in French or English) or their curricula vitae, qualifications, reprints of papers published in the last year, and a description of the research for which the prize is claimed.

\section{People in the News}

Professor A. Mair, of the department of community and ocoupational medicine, University of Dundee, has been awarded the Abencrombie prize for his biography of Sir James Mackenzie.

Professor R. Miledi, F.R.S., professor of biophysios at University College, London, has been awanded the Royal Society's Foulerton research professorship, from 1 March. He will continue to work at University College.

Professor H. G. Wittman and Dr. J. B. Gunden, F.R.S., are the prizewinners of the Feldberg Foundation awards for 1975.

\section{COMING EVENTS}

Asian Federation of Obstetrics and Gynaecology.-First Inter-congress, Singapore, 27-30 April. Details from 1st A.F.O.G. Secretariat, K. K. Hospital, Hampshire Road, Singapore 8.

Royal Society of Medicine.-1975 International Symposium on Influenza Vaccination, 29-30 April, London. Details from Miss Diana O'Connell, Biggs Communication Group Ltd., Red Lion House, High Street, High Wycombe, Bucks.
HP11 2BX. (Tel. 0494 23341).

"Medical Aspects of Sport of the Disabled."International postgraduate seminar, 9-10 May, Stoke Mandeville Sports Stadium for the Paralysed and Other Disabled. Details from the Secretary General, Stoke Mandeville Sports Stadium for the Aylesbury, Bucks. (Tel. 0296 84848).

Royal College of Pathologists. - Joint meeting with the Association of Clinical Biochemists at Middlesex Hospital, Tuesday, 13 May, to discuss the role of the supraregional assay laboratories in clinical laboratories. Details from Professor R. Ekins, Institute of Nuclear Medicine, Middlesex Hospital Medical School, Nassau Street, London,

"The Family and Mental Health."-Community Mental Health course, 16 May-12 July. Details and programme from The Short Course lebone Road, London. (Tel. 01-486 5811 ext. 252).

Medical Council on Alcoholism.-Day symposium for medical students "Alcohol and Alcoholism," 23 May, Royal College of Physician` of London. Details from Executive Director, Medical W1X 9HY. (Tel. 01-493 0081)

"Development and Use of Safe and Effective Drugs." -International symposium on drug safety, 17-18 June, Ottawa, sponsored by the Drugs Directorate, Health Protection Branch, Canada. Fee \$50. Details from Mrs. Jean Anderson, Technical Secretariat, Room 1-12, Healt Protection Branch Building, Health and Ottawa, Ontario, Canada K1A OL2.

Royal College of Physicians of London.Teach-in, "Multiple Sclerosis," 6 May. For details see advertisement on page xiii.

10th International Congress of Gerontology. $-22-27$ June, Jerusalem. Details from the secIsrael.

International Symposium on Gastrointestina Emergencies. - 15-18 September, Stockholm sponsored by Swedish Ministry of Education and Swedish M.R.C. The closing date is 1 June and details are obtainable from Dr. F. Bárány, Depart11282 Stockholm, Sweden.

University of Aberdeen.-Copies and details of the Medical Faculty lectures for the Summer Term are obtainable from the Administrative Aberdeen, AB9 1AS. (Tel. 0224 40241).

\section{SOCIETIES AND LECTURES}

For attending lectures marked a fee is charged or a ticket is required. Applications should be made first to the institution concerned.

Monday, 28 April

Royal College of Surgeons of England -4.30 p.m., Erasmus Wilson

\section{Tuesday, 29 April}

Royal College of Surgeons of England. - 4.30 p.m., Arnott demonstration by Dr. J. A. Clarke

RoYal ARMY Medical Collegr.-5 p.m., Professor : Aspects of Malaria.

\section{Wednesday, 30 April}

Charing Cross hospital Medical School.-5.30 p.m., Professor E. H. Ashton: Biometry-An INSTITUTE OF PSYCHIATRY.-5.30 p.m., Professor H. Gwynne Jones: The Changing Face of Behaviour Therapy.

RoyAL FreE Hospital.-5 p.m., Dr. A. C. Bear (U.S.A.): Genetic Aspects of. Common Diseases. RoYAL POSTGRADUATB MEDICAL SCHOOL. 2 p
Dr. R. Riddell: Systemic Fungal Infeotion.

\section{Thursday 1 May}

ROYAL SOCIETY OF MEDicine.-5 p.m., Second Edith Whetnall lecture by Professor W. G. Hardy Baltimore): Some Dimensions of Hearing and ST. JOSEPH's Hospice.-8 p.m., Sister I. Steel: Relatives in the Ward.
T. MARY's Hospital MEDICAL SCHOoL- -5.15 p.m. Dr. T. G. Baker: The Ovary and Ovulation.

Friday, 2 May

ROYAL COLLEGE OF SURGEONS OF ENGLAND.-At At p.m., Moyihan lecture by Professor M. Allgöwer: RoYal PostGRaduate Medical School.-11 a.m.. Professor W. H. McArthy: The Treatment of Disseminated Melanoma.

\section{UNIVERSITIES AND COLLEGES}

LONDON

M.S. $\rightarrow$ S. B. R. Desai.

ROYAL COLLEGE OF SURGEONS OF

At the ordinary meeting of the council held on 10 April, with Sir Rodney Smith, president, in the chair, Professor Jean-Louis Lortat-Jacob was elected

Dr. V. F. Hall, Sir Geoffrey Organe and Professor Fellowship of the were elected to the Honorary Professor the

the Faculty of Anaesthetists and elected dean Sellick elected vice-dean from The following were elected to Fellowship without F.R.C.S.-Dr. D. Dooley, Dr. F. Kohn, Dr. R. G. W. Ollerenshaw, Mr. G. J. Romanes, Mr. F.D.S.R.C.S. Dr. A. J. Whofessor R. Hartles, Mr. D. Matthews, Professor H. Obwegeser, Dr. H. Worth. The John Tomes prize was awar

warded to Professor Professor R. A. Cawson was elected Charles Tomes Lecturer for 1976 .

Dr. D. D. C. Howat was elected Frederic Hewitt Lecturer for 1977

Evelyn Sprawson prizes were awarded to Dr. Jacqueline Orchard and Dr. R. J. Middlehurst.

Diplomas in tropical medicine and hygiene were warded jointly by the Royal College of Physicians of England to the Royal College of Surgeons of Hayat, Dr. I. Mohammed, Dr. C. N. Obionu, and Dr. Jolanta B. Powalowska.

Certificates of completion of higher surgical training were granted to Mr. M. H. Calvert, Mr. Richards, Mr. J. R. C. Gardham, Mr. R. W. Mr. A. S. Chilvers, Mr. R. L. Doig, Mr. D. Negus, nd Mr. A. G. A. Cowie.

Diplomas in orthodontics were granted to $R$. W Rosamund G. Mirks, E. Dekonor, Marie Kosloff, and C. Sivanesan.

\section{Corrections}

Peripheral Neuropathy and Indomethacin

In the paper by $O$. E. Eade and colleagues April, p.66) the table giving results of nerve conduction studies should have shown forearm/leg velocity for right ulnar motor Inerve as $33 \mathrm{~m} / \mathrm{s}$ in July $1973^{\circ}$ and $51 \mathrm{~m} / \mathrm{s}$ in June 1974

\section{Notice to Authors}

When original articles and letters for publication are not submitted exclusively to the British Medical fournal this must be stated.

Correspondence on editorial business should be addressed to the Editor, British Medical fournal, B.M.A. House, Tavistock Square, London
WCiH 9JR. Telephone: 01-387 4499. Telegrams: Aitiology, London, W.C.1.

Authors wanting reprints of their articles should notify the Publishing Manager, B.M.A. House, Tavistock Square, WC1H 9JR, on receipt of proofs.

\section{(O) British Medical Journal 1975}

All Rights Reserved. No part of this publication may be reproduced, stored in a retrieval system, or transmitted, in any form or by any means, electronic, mechanical, photocopying, recording or otherwise, without the prior permission of
the British Medical fournal. 